\title{
The spatial distribution of foreign direct investment in R\&D within host countries. An empirical examination of foreign subsidiaries in Spain
}

\author{
Adelheid Holl \\ Institute of Public Goods and Policies (IPP), \\ CSIC - Consejo Superior de Investigaciones Científicas, \\ C/ Albasanz, 26-28; 28037 Madrid, Spain \\ Email: a.holl@csic.es

\section{Ruth Rama*} \\ Institute of Economics, Geography and Demography (IEGD), \\ CSIC - Consejo Superior de Investigaciones Científicas, \\ C/ Albasanz, 26-28; 28037 Madrid, Spain \\ Email: ruth.rama@cchs.csic.es \\ *Corresponding author
}

\begin{abstract}
We discuss the patterns of foreign direct investment in R\&D within host countries and provide an empirical analysis for Spain by comparing foreign subsidiaries' $\mathrm{R} \& \mathrm{D}$ location patterns with that of domestic plants. We find that foreign subsidiaries' R\&D is strongly concentrated in Madrid and Catalonia, the two largest Spanish regional agglomerations. Networked foreign subsidiaries involved in external technology sourcing still centralise to a greater extent their R\&D activities in these leading regions. The concentration of foreign direct investment in R\&D is significantly greater than that of domestic firms' R\&D. The most technologically intensive foreign subsidiaries, however, are not attracted to Madrid, in spite of the alleged advantages of global cities in terms of openness and connectivity; but this is not a specificity of foreign subsidiaries as we observe a similar pattern for domestic firms.
\end{abstract}

Keywords: Spanish regions; foreign subsidiaries; R\&D; innovation; networking; Spain.

Reference to this paper should be made as follows: Holl, A. and Rama, R. (2016) 'The spatial distribution of foreign direct investment in R\&D within host countries. An empirical examination of foreign subsidiaries in Spain', Int. J. Multinational Corporation Strategy, Vol. 1, No. 1, pp.65-86.

Biographical notes: Adelheid Holl holds a tenure position as Researcher at the Institute of Public Goods and Policies at the Spanish National Research Council (CSIC). Previously she worked as Ramón y Cajal Research Fellow at the Fundación de Estudios de Economía Aplicada (FEDEA, Madrid) and as Lecturer in the Department of Town and Regional Planning at the University of Sheffield, UK. She has a Master's in Regional and Urban Planning from the London School of Economics and a PhD in Town and Regional Planning from the University of Sheffield. Her main research interests are in economic geography; including industrial location and spatial firm behaviour. She has published in refereed journals such as Journal of Urban Economics, Journal of 
Economic Geography, Regional Science and Urban Economics, Journal of Regional Science, Papers in Regional Science, Industry and Innovation, Science and Public Policy, and European Planning Studies.

Ruth Rama is a tenured Research Professor at the Institute of Economics, Geography and Demography of the Spanish National Research Council (CSIC). She has a $\mathrm{PhD}$ degree from the Autonomous University of Barcelona. Her main research interests are in multinational enterprises and their interplay with national innovation systems; networks of innovators, and location of the R\&D activities of firms. She has published in refereed journals such as Environment and Planning A, Urban Studies, Technovation, Research Policy, Journal of Technology Transfer, International Journal of Technology Management, Science and Public Policy, European Planning Studies, Regional Studies, and Industry and Innovation.

This paper is a revised and expanded version of a paper entitled 'Location of R\&D foreign direct investment in Spanish regions' presented at the 53rd ERSA (European Regional Studies Association) Congress, Palermo (Italy), 27-31 August 2013.

\section{Introduction}

Multinational enterprises (hereafter, MNEs) may play an important role in international technology transfer because of their global production networks and because they are often technologically superior to domestic firms (Veugelers and Cassiman, 2004). However, many foreign direct investment (hereafter FDI) schemes are unlikely to fulfil policy makers' expectations concerning the development of regional industrial capabilities (McCann and Mudambi, 2004). The risk of a branch plant syndrome may exist when subsidiaries source knowledge internally or interact exclusively with the rest of the MNEs (Phelps, 1993). Also, MNEs may centralise their R\&D activities in some specific locations within host countries, and not in others.

Though there now exists a rich literature on the regional location of foreign subsidiaries (see, for example, Guimarães et al., 2000; Crozet et al., 2004; Hilber and Voicu, 2010; Mariotti et al., 2010; Villaverde and Maza, 2015) ${ }^{1}$, research work on the specific location of their R\&D activities is much more limited. Our study is aimed at filling certain gaps in this literature by providing an empirical analysis of the Spanish case. Though previous studies have contributed important insights, certain aspects concerning the regional location of FDI in R\&D within host countries probably deserve more attention. Firstly, while the extant literature has mainly focused on highly industrialised countries, our article provides a specific focus on a catching up country. Secondly, previous research has mainly focused on factors determining the attractiveness of host regions for FDI in R\&D. There is no doubt now that the availability of regional knowledge sources constitutes a strong attraction for foreign-owned R\&D (see, for instance, Frost and Zhou, 2000; Mariani, 2002; Cantwell and Piscitello, 2002, 2005; Belderbos et al., 2014). In contrast, even in the general FDI literature, "there is little theoretical or empirical work on the influence of firm characteristics on the location choices of MNEs" [Goerzen et al., (2013), p.1]. With the exception of the literature concerning the matching of the technological characteristics of MNEs and the 
technological characteristics of host regions (see, for instance, Cantwell and Piscitello, 2005), our knowledge of the relationships between, more specifically, the strategies of foreign-owned R\&D and its sub-national location is still limited. Here, our aim is less to analyse the characteristics of the host regions that attract FDI in R\&D and more to explore the characteristics of FDI in R\&D attracted to different sub-national locations.

As stated, the strategies of FDI in R\&D may or may not benefit host countries and host regions. We are mainly interested in two types of foreign subsidiaries which may especially benefit host countries or host regions that are not at the forefront in science and technology. Of special interest are those foreign subsidiaries that pursue an open innovation strategy, as opposed to firms that perform $R \& D$ exclusively within the establishment or within their business group. It is these firms that may link local firms to international know-how networks. Therefore, we specifically explore the R\&D location of foreign subsidiaries engaged in external technology sourcing compared to similar domestic firms. We also explore the location strategy of technology leaders (definition below) since they are likely to bring state-of-the art technology, their technological level being well above that of host industries.

Finally, most previous studies use patent data granted to the world's leading MNEs to study the location strategy of FDI in R\&D within host countries (see Appendix 1). This methodology is certainly suitable to analyse the regional location of the most valuable innovative activities of these companies in highly developed countries (Cantwell and Iammarino, 2000) but may be inappropriate for studying peripheral European countries, such as Spain, or emerging economies. Patent information is insufficient for evaluating the total potential contribution of FDI to local technological upgrading. Innovative activities that are never patented may, nevertheless, be valuable for host countries and host regions, and all types of MNEs need to be included in the analysis (not exclusively world leaders). Actually, a few studies focus on the location of the R\&D activities of foreign subsidiaries (not on the 'locus' of their patented inventions) (see, for instance, Ho, 2006; Siedschlag et al., 2013). A difficulty, however, is that domestic firms are often excluded from these analyses. We believe analysing foreign subsidiaries in isolation may not be sufficient to understand their specific spatial strategy: comparing R\&D subsidiary location to the R\&D location patterns of domestic firms can improve our understanding of such possible specificities. One of the few exceptions in this literature is Autant-Bernard (2006), who analyses the location decision of R\&D labs in France and controls for foreign-ownership status. She shows that foreign-owned R\&D labs were more likely to locate in the main industrial regions as well as in frontier regions. Our study is also one of the few that analyse the sub-national distribution of foreign-owned $\mathrm{R} \& \mathrm{D}$, while using domestically-owned corporate $\mathrm{R} \& \mathrm{D}$ as a control group.

Several reasons make the case of Spain especially interesting for exploring these issues in a catching-up country. Within the European Union (EU), Spain is a major receiver of FDI. In 2011, inward stock of FDI was 634.5 billion US\$. To put this figure into perspective, observe that in the same year the Netherlands accounted for 589 billion US\$ and Germany for 713.7 US\$ (UNCTAD, 2012). Spain is the sole peripheral European country to have one of its regions (Madrid) classified among the Top 10 regional receivers of inward FDI in 2000-2006 (Villaverde and Maza, 2015). Another reason is that Spain has a quasi-federal structure, and this circumstance may lead economic actors to reshape their strategies at regional level (Royo, 2008). Finally, the Spanish Technological Innovation Panel (Panel de Innovación Tecnológica, PITEC), 
gives richer regional information than that provided by the Community Innovation Surveys (CIS) of the EU for other peripheral European countries.

We show for Spain that foreign subsidiaries are more likely than domestic firms to concentrate their innovative activities in a few geographical locations within the host country. We maintain, however, that foreign subsidiaries are not a homogeneous group. Their technology sourcing strategies and their R\&D intensity seem to influence the regional location of their R\&D activities.

Section 2 discusses the literature and presents our hypotheses. Section 3 presents the research context and the data, Section 4 contains the analysis and discussion of results and Section 5 concludes.

\section{Literature review and hypotheses}

Most of the general literature on the sub-national location choices of foreign subsidiaries concludes that these companies are attracted by the largest economic agglomerations in the host country (see, for instance, Dunning, 1998; Mariotti and Piscitello, 1995). Already established multinationals might facilitate information about the location and so reduce search costs and uncertainty involved in the location decision process (Guimarães et al., 2000; Head and Mayer, 2004; Mariotti et al., 2010). Other attractors for the location of firm's headquarters are the availability of urban service agglomeration economies (Guimarães et al., 2000; Hilber and Voicu, 2010), good international transport infrastructure and non-stop intercontinental flights (Bel and Fageda, 2008). At the same time, the largest agglomerations are often the technologically most advanced areas of host countries.

Especially interesting types of agglomerations are the so called global cities. These cities play a role as the principal location for globally connected firms. They are not necessarily very large but they display key features such as 'connectivity', 'openness' and 'accessibility' (Iammarino and McCann, 2013). These authors observe a "correspondence between global cities-regions and the location behaviour of MNEs" (p.316), an opinion which seems to be empirically confirmed (Goerzen et al., 2013). Villaverde and Maza's (2012) study on the sub-national distribution of FDI in Spain finds that two key components of agglomeration economies, namely infrastructures and per capita GDP, positively attract FDI while another component, market size, is not significant in their econometric analysis.

Shaver (1998) and Voinea and Van Kranenburg (2011) show respectively for the USA and the Netherlands, that foreign-owned firms follow a different location pattern than domestic firms.

There is now a considerable literature on the international R\&D activities of MNEs (for reviews, see Dunning and Lundan, 2009; OECD, 2005). MNEs perform R\&D in the host country for a variety of reasons, such as adapting products to local regulations, ingredients and tastes or getting access to skilled researchers. As stated, the empirical literature on the location, more specifically, of FDI in R\&D within host countries is still limited and most of the studies focus on regional attractors of MNEs (for selected examples, see Appendix 1). An important conclusion of this literature is that R\&D activities may be driven by different location motivations than downstream activities of the company (Frost and Zhou, 2000; Defever, 2006; Crescenzi et al., 2014). Traditional regional advantages such as low salaries seem less important to specifically attract $R \& D$ 
foreign investments. In contrast, the scale and specialisation of technical activity performed by firms and universities in a region may be a driver of FDI in R\&D (Frost, 2001; Cantwell and Iammarino, 2000; Cantwell and Piscitello, 2002, 2005; Mariani, 2002; Siedschlag et al., 2013; Belderbos et al., 2014). Locating in those areas can allow foreign subsidiaries to take advantage of local knowledge spillovers and thus facilitate technology sourcing. Concerning the location of R\&D activities, foreign subsidiaries seem to be even more sensitive than domestic firms to the advantages of agglomerations (Cantwell and Piscitello, 1999). Foreign subsidiaries may absorb new knowledge more easily through geographically close relationships with clients, suppliers, competitors or local institutions (Almeida, 2004; Andersson et al., 2005). The technological characteristics of locations are, according to some authors, becoming more important to MNEs than drivers traditionally viewed as key explanations for location decisions, such as low-cost factor inputs or labour market characteristics (Frost and Zhou, 2000; Villaverde and Maza, 2015).

Do the innovative activities of foreign subsidiaries tend to agglomerate to a greater extent than those of domestic firms? This question is still controversial. A study on the Irish electronics industry found that the location decisions of domestic and multinationals firms concerning their R\&D activities tend to differ, although there are examples of regional clusters which include both types of firms (Kearns and Görg, 2002). Cantwell and Piscitello (2005) observed that foreign-owned R\&D activities in European regions are more concentrated than domestically-owned R\&D activities; an exception is the UK. The location of foreign-owned R\&D activities may be affected by that of domestically-owned R\&D activities. Cantwell and Piscitello (2005) found that the agglomeration of highly innovative domestic companies in a region is likely to produce a crowding-out effect and deter foreign subsidiaries. A study on European small country regions notes a similar crowding-out effect but only affecting technologically weak European-owned MNEs (Cantwell and Santangelo, 2002). Working with detailed Italian data, Mariotti et al. (2010, p.519) observed that MNEs tend not to agglomerate with domestic companies because "they perceive potential knowledge inflows to be lower than potential leakages, unless domestic companies enjoy some comparative advantages". Therefore, we hypothesise:

H1 Patterns of R\&D location differ in foreign subsidiaries and domestic firms.

Most studies admit that innovation has a strong regional character, one reason being that networking facilitates information exchanges and technology diffusion. Regional networking seems to chiefly benefit small and medium-sized enterprises (SMEs), since the presence of proximate external sources of knowledge may contribute to counteracting the paucity of their own resources (Almeida and Kogut, 1997). The previous discussion suggests that MNEs may also benefit from agglomeration economies. However, certain authors identify important exceptions (Cantwell and Santangelo, 2002; Cantwell and Piscitello, 2005; Mariotti et al., 2010), and their research work points to the heterogeneity of MNEs in this respect.

Narula and Santangelo (2012) opine that, while the innovation system literature argues in favour of the close clustering of firms for R\&D activities, recent research seems to challenge this view. In fact, these authors opine, "more capable firms collocate less than less-capable firms" (p.18). The strategic deterrence literature argues that the geographical clustering of firms may suffer from the problem of adverse selection since laggard firms may have more to gain from physical proximity to other firms while 
technologically advanced firms may have more to lose, owing to the risk of involuntary spillovers (Cantwell and Mudambi, 2011). The empirical literature provides some support for this view (Suárez-Villa and Walrod, 1997; McCann and Mudambi, 2005; Suárez-Villa, 2002; Alcácer and Chung, 2013). Studying the location of foreign subsidiaries in the USA, Shaver and Flyer (2000) find that those that cluster are less likely to survive, and they attribute this phenomenon to agglomeration disadvantages. Since their knowledge may leak to co-located competitors, leading companies may prefer to avoid regional agglomerations. A case study based on the responses of seven of the most innovative foreign subsidiaries in Spain shows that they are not especially eager to locate their R\&D activities in large scale districts; profiting from local spillovers is not a priority for them (Miravitlles et al., 2013).

Therefore, we put to test the following hypothesis:

H2 Innovative foreign subsidiaries are not likely to agglomerate.

\section{Research context and data}

As stated, Spain is an important receiver of FDI. According to the RIE (Spanish Register of Foreign Investment), FDI stock was mostly concentrated in 2003-2011 in manufacturing sectors, such as food, beverages and tobacco, and automobiles, and in services, such as banking (Fernández-Otheo, 2014). Surveying a group of large foreign innovators located in Spain, Miravitlles et al. (2013) found that the companies had been attracted by the size of the market, the government R\&D policy, and the availability of qualified suppliers and staff.

As in most previous studies on the sub-national distribution of foreign-owned R\&D, we focus on EU NUTS 2 regions (Nomenclature of Territorial Units for Statistics) ${ }^{2}$. Spanish regions have a considerable degree of autonomy and fiscal prerogatives, and develop their own spatial programmes. They also differ due to their different Revealed Technological Advantages (RTA). For instance, patent analysis for 1978-1997 shows that Madrid has RTA mainly in spatial technology and defence, telecommunications and information technology; Catalonia, in chemical engineering, semiconductors, agriculture and food processing equipment, and vehicles (Sanz Menéndez and Arias, 1998). The Basque Country has RTA in machine tools, metallurgy, and thermal technology and processes. Valencia has RTA in image and sound technology, medical technology and consumer goods technology.

Our data come from the Spanish Technological Innovation Panel (Panel de Innovación Tecnológica, PITEC), a survey carried out by the Spanish Statistical Office (INE). The survey is quite similar to the CIS of the EU but, as stated, provides richer information. PITEC is a mandatory survey and, in 2007, 96.2\% of the firms surveyed filled in the questionnaire (the rest refused to cooperate, had moved, etc.). This high response rate contributes to the representativeness of the data concerning sector, region and ownership. The PITEC sample is representative of manufacturing and service firms located in Spain; foreign subsidiaries, constituting slightly over $10 \%$ of all private companies. ${ }^{3}$ In order to check whether the PITEC data are representative concerning the geographic distribution of foreign subsidiaries within the host country, we compared the PITEC data on the location of the main office of these companies with those of another INE survey, the FLINT survey (Foreign Affiliate Statistics on Spain) ${ }^{4}$. The FLINT data 
come from an exhaustive survey (not a sample) and report, therefore, on the population of foreign subsidiaries in Spain; they are representative of the regional distribution of these companies. FLINT follows the FATS (Foreign Affiliate Statistics of EUROSTAT) methodology. For 2008, no statistically significant difference was found between the PITEC and FLINT databases regarding the spatial distribution of the main offices of foreign subsidiaries $\left(X^{2}=4.7480 ; p=0.1912039\right)$. Therefore, the PITEC database can be considered representative regarding the geographical distribution of foreign subsidiaries within Spain. PITEC includes information on the technological innovation activities of all the main sectors in the Spanish economy. In addition to information on the location of the main office, PITEC also gives detailed information on the regional location of companies' R\&D employees. Firms are asked to state the number of R\&D employees in each of the 19 autonomous regions and cities of Spain. This information allows us to identify all firms with R\&D employment by region. It should be noted that we use plantlevel data. Therefore, the analysis of a large national database for a catching-up country, which allows us to compare the R\&D location strategies of domestic firms and foreign subsidiaries, is a contribution of our article.

Following Frost and Zhou (2000), we view foreign R\&D as a cumulative process in host country locations and, therefore, do not limit the analysis to solely the geography of 'new' facilities. However, we also present some tests for new firms in order to understand current location decisions which are not influenced by past decisions of firms. New foreign subsidiaries often display less openness than established foreign subsidiaries, relying mainly on their multinational network for technology. Therefore, considering their strategies may be useful given our focus on external technology sourcing. As stated, we are especially interested in the location of the R\&D facilities of networked foreign subsidiaries and networked domestic firms. We define networked companies as those which are involved in external technology sourcing, as opposed to those sourcing technology exclusively within their own establishment or their business group. External technology sourcing includes two categories:

1 R\&D outsourcing (purchasing or subcontracting of R\&D services)

2 cooperation for innovation.

Both activities are undertaken with external agents, i.e. partners or suppliers external to the business group of the focal firm (e.g. independent companies, universities and consultants). Note that for cooperation activities, only innovation-active firms were asked questions related to their cooperation. These are firms that have introduced new products or new processes or that have ongoing innovative activities or abandoned such activities during the two years prior to the date of the survey. Thus, the sample for R\&D cooperation is smaller than the sample for technology outsourcing, which includes both innovators and non-innovators. We have 11,196 observations for R\&D outsourcing and 8,382 for cooperation of innovation.

The sector categories are from the CNAE (National Classification of Economic Activities), similar to NACE rev 1, the classification of economic activities used in EU statistics, which we aggregated into 43 sectors. These data are introduced in the analysis in order to take into account the sectoral disparities among regions. 55\% of the sample foreign subsidiaries do not perform R\&D in Spain. The rest tend to centralise these activities in a single Spanish region (38\% of the sample); only $7 \%$ prefer to disperse their R\&D activities geographically in two or more regions. 
As stated, we maintain that patent analysis is a rather limited method for analysing the regional distribution of FDI in R\&D in peripheral European countries or in emerging economies since, in these countries, the number of patents generated by foreign subsidiaries at the regional level may be very small (or non-existent). Even in a highly industrialised country, the number of patents granted to foreign-owned labs may be very small in specific regions and this circumstance may pose statistical difficulties (Cantwell and Iammarino, 2000). Patent protection is sought for highly valuable inventions, not just for any type of invention, for instance, mere ameliorations of a product or industrial process. Leading MNEs tend to perform valuable research in world centres of excellence rather than in peripheral locations. In contrast, they may perform $R \& D$ in many sites. Even if these innovative efforts at times do not deserve patent protection, they may contribute to the upgrading of domestic industries and services. This is especially the case for host countries that are not at the forefront in science and technology, such as Spain. Therefore, we prefer to use R\&D data. However, it may be argued that the simple regional distribution of $R \& D$ employees does not take into account qualitative aspects of innovation. Thus, we also introduce patents in the econometric analysis in order to control for innovations that deserve special legal protection, probably due to their high technological or commercial value. Table 1 displays a description of the variables that we have used in the statistical analyses reported in the next section.

Table 1 Survey variable description

\begin{tabular}{|c|c|}
\hline Variable & Definition \\
\hline Foreign subsidiary status & Private company with at least $50 \%$ of foreign capital \\
\hline R\&D employment & Number of corporate R\&D employees. \\
\hline \multirow[t]{3}{*}{ Location } & R\&D employment $>0$ in region $i$. \\
\hline & $\begin{array}{l}\text { Loc } 1 \text { takes on } 1 \text { if the firm is located in Madrid, } 2 \text { if the firm is } \\
\text { located in Catalonia and } 3 \text { otherwise. }\end{array}$ \\
\hline & Loc 2 takes on 1 if the firm is located in Madrid and 0 otherwise. \\
\hline External R\&D outsourcing & $\begin{array}{l}\text { Dummy variable taking on } 1 \text { if the firm acquires } R \& D \text { services } \\
\text { from outside the own company group and } 0 \text { otherwise. }\end{array}$ \\
\hline $\begin{array}{l}\text { External cooperation } \\
\text { for innovation }\end{array}$ & $\begin{array}{l}\text { Dummy variable taking on } 1 \text { if the firm reports joint innovative } \\
\text { activities with institutions and other companies outside the own } \\
\text { company group and } 0 \text { otherwise. }\end{array}$ \\
\hline Internal R\&D expenditure & Corporate internal R\&D expenditure in region $i$. \\
\hline Total innovation expenses & $\begin{array}{l}\text { Total corporate expenditures in design, patent acquisition, } \\
\text { activities meant to introduce new products into the market in } \\
\text { region } i \text {. }\end{array}$ \\
\hline Technologically advanced & $\begin{array}{l}\text { Dummy variable taking on } 1 \text { if the company is in the top quartile } \\
\text { in terms of the number of } R \& D \text { employees per total sales in its } \\
\text { respective technology sector* and year. }\end{array}$ \\
\hline Size $(\log )$ & Log of the total number of employees. \\
\hline Patents & $\begin{array}{l}\text { Dummy variable taking on } 1 \text { if the company has been granted } \\
\text { patents and } 0 \text { otherwise. }\end{array}$ \\
\hline Export & $\begin{array}{l}\text { Dummy variable taking on } 1 \text { if the company is an exporter } \\
\text { and } 0 \text { otherwise. }\end{array}$ \\
\hline Year of creation & Year the company was established. \\
\hline Industry & Dummies for 43 industry sectors. \\
\hline
\end{tabular}


In Spain, the two leading industry and service regions are Madrid and Catalonia, followed in importance by the Basque Country and Valencia. The 2009 Regional Innovation Scoreboard of the EU, based on a variety of science and technology indicators, classified Madrid and the Basque Country as follower-high innovators (comparable, for instance, to the Walloon Region); Catalonia as a follower-medium innovator and Valencia as a moderate medium innovator (European Commission, 2009). Valencia was also the least affluent of the four economic groupings in 2007. The GDP per inhabitant was quite similar in Madrid and the Basque Country $(34,000 €$ and $34,100 €$, respectively), while it was lower in Catalonia $(30,700 €)$ and, especially, in Valencia $(23,700 €)$. The data provided by the Scoreboard suggests that there is no clear ranking of Madrid and the Basque Country concerning R\&D regional technical resources.

Villaverde and Maza (2012) noted that in Spain, FDI concentrated in Madrid and, to a much lesser extent, Catalonia. Following UNCTAD methodology, they calculated a Performance Index (regional amount of inward FDI/regional GDP ratio); in 2001-2005, Madrid had a Performance Index of 3.316 indicating that the region obtained a share of Spanish inward FDI more than three times greater than its share of GDP. The other Spanish regions displayed Performance Indices below one. Following, they measured the potential attractiveness of regions by calculating a Potential Index as measured by per capita GDP, average years of schooling, R\&D expenditure/GDP and so on. They noted that, over 1995-2005, Madrid continued to be a privileged location for FDI but that the Basque Country and Navarre tended to slightly outweigh Madrid. In another study (Villaverde and Maza, 2015), they extended the analysis to 260 EU regions. In 20002006, Madrid was classified in a group of EU 'front-runners' combining both high actual performance and high potential to attract FDI. None of the other Spanish regions was in this group. Most of the 'front-runners' were Belgian, British, Dutch and Swedish regions. Not only has the amount of FDI across regions differed but also the industrial specialisation of foreign subsidiaries. In 1995-2008, Madrid attracted more FDI in high technology sectors than the Spanish average but was clearly surpassed by Catalonia in this area (Villaverde and Maza, 2012). However, Catalonia also attracted substantially more FDI in low-technology industries than average. In turn, the Basque Country tended to attract more FDI operating in medium technology industries than the Spanish average.

\section{Empirical analysis and discussion}

\subsection{Spatial pattern of location of foreign $R \& D$ activities}

We start by comparing the presence of foreign subsidiaries with R\&D activities in the four leading Spanish regions (Madrid, Catalonia, Valencia and the Basque Country) and in the rest of the country. Table 2 shows the percentage of foreign subsidiaries in the total number of private companies in our sample in these regions compared to the rest of the country. The rest of the country includes all the Spanish regions minus the four mentioned above. The comparison is based on the number of companies with $R \& D$ employment and the spatial distribution of their R\&D centres among Spanish regions. The two leading regions, Madrid and Catalonia, host disproportionally more foreign R\&D activities than the rest of the country. Outside the four main industrial regions, about $10 \%$ of our sample firms are foreign subsidiaries with R\&D employment. In Madrid and Catalonia approximately $15 \%$ of sampled private companies with R\&D 
employment belong to foreign multinationals. In contrast, the Basque Country and Valencia show lower than average representation of foreign R\&D activities, though the difference with the rest of the country is only statistically significant for Valencia. Thus, only two leading regions (Madrid and Catalonia) enjoying both high per capita GDP and high levels of technology at the same time, display significant concentration levels of foreign R\&D activities. The Basque Country, both affluent and technology-rich, did not significantly attract FDI in R\&D above the rest of the country. This case is discussed below.

Table 2 Location of sample subsidiaries that perform R\&D

\begin{tabular}{lccc}
\hline & $\begin{array}{c}\text { \%o of subsidiaries as share } \\
\text { of total private companies }\end{array}$ & $\begin{array}{c}\text { t-test of means difference } \\
\text { compared to rest of Spain }\end{array}$ & $\begin{array}{c}\text { Sig. } \\
\text { Madrid }\end{array}$ \\
Catalonia & 15.2 & -4.903 & $* * *$ \\
Basque Country & 15.3 & -6.284 & $* * *$ \\
Valencia & 9.1 & 0.795 & $* *$ \\
Rest of country & 7.0 & 2.471 & \\
\hline
\end{tabular}

Notes: ***Significant at the $1 \%$ level; **significant at the $5 \%$ level; * significant at the $10 \%$ level. The t-test compares the percentage of foreign subsidiaries in the four specific regional economic agglomerations to the percentage of foreign subsidiaries outside these four regional agglomerations.

Source: Authors' calculations based on PITEC

The concentration in Madrid and Catalonia is even more pronounced for networking foreign subsidiaries with R\&D employment, defined as those that have R\&D outsourcing linkages or some type of cooperative relations for innovation with other independent companies or institutions (Table 3). We repeat the two tests for similar domestic firms (results available upon request). Our results support the view that, regarding R\&D activities, foreign subsidiaries are more sensitive than domestic firms to the attraction of agglomerations (Cantwell and Piscitello, 1999).

Table 3 Location of networking foreign subsidiaries that perform R\&D

\begin{tabular}{lccc}
\hline & $\begin{array}{c}\text { \% of networking subsidiaries as share } \\
\text { of total networking private companies }\end{array}$ & $\begin{array}{c}\text { t-test of means difference } \\
\text { compared to rest of Spain }\end{array}$ & Sig. \\
\hline Madrid & 17.2 & -4.543 & $* * *$ \\
Catalonia & 16.4 & -4.580 & $* * *$ \\
Basque Country & 9.2 & 0.520 & 1.037 \\
Valencia & 8.2 & & \\
Rest of country & 10.0 & & \\
\hline
\end{tabular}

Notes: $* * *$ Significant at the $1 \%$ level; $* *$ significant at the $5 \%$ level; * significant at the $10 \%$ level. The t-test compares the percentage of foreign subsidiaries with networking activities ( $R \& D$ outsourcing or cooperation) in the four specific regional economic agglomerations to the average percentage of networking foreign subsidiaries outside these four regional agglomerations.

Source: Authors' calculations based on PITEC

According to PITEC data, Madrid and Catalonia together account for $65 \%$ of all foreign multinational R\&D employment, $80 \%$ of their internal $R \& D$ expenditure, and $73 \%$ of 
their innovation expenses (for definitions, see Table 1). In contrast, other regions display a very limited presence of multinational innovative activities. For instance, the contribution of domestic firms to regional corporate R\&D expenditure is outstanding in regions such as Galicia (92.3\% of total) and Castilla-La Mancha (93.8\%). These regions are not very attractive for FDI in R\&D.

Results are comparable to those found for France, Italy and the UK (but not for Germany), where FDI in R\&D also tends to cluster heavily in a few sites (Cantwell and Piscitello, 2005). They also support the idea that the R\&D activities of foreign subsidiaries are likely to be more tied to technology rich host regions (Almeida, 2004).

However, an important exception is the Basque Country, the most affluent of the four regions analysed here and a technology rich region. A plausible explanation is provided by theories of regional advantage. Since the amenities and the general climate of regions are important to attract human capital related to creative activities such as R\&D and design (Asheim et al., 2007), reasons for FDI in R\&D not clustering there are probably related to terrorist conflict during those years (for an analysis of the economic costs of terrorist conflict in the Basque Country, see Abadie and Gardeazabal, 2003). This interpretation is in line with international business (IB) theory, since political stability is considered as a region level L (location) advantage (Narula and Santangelo, 2012). According to RIE data, in 2003-2011 the total assets of foreign subsidiaries rose $61.3 \%$ in the whole country, while they fell $12.5 \%$ in the Basque Country (Fernández-Otheo, 2014). In the IB literature, it is an established fact that FDI in R\&D tends to follow productive FDI (Blanc and Sierra, 1999). Therefore, the reduction of their regional assets may have negatively affected the level of the R\&D activities performed by foreign subsidiaries in the Basque Country. Other explanations for the specificity of the region are plausible. In the 1990s, Ferreiro et al. (1997) traced the greater attractiveness of Madrid and Catalonia for FDI, as compared to that of the Basque Country, to lower labour unit costs, greater industrial diversification and a more rapid pace of growth of regional demand. In their view, another reason why the Basque Country was less attractive for FDI was the decline of its 'old' regional industries, such as steel.

In a context of conflict and devastating industrial crises, the Basque Country has, nevertheless, forged a new regional model largely inspired by Italian districts and Porterian views on industrial clusters (Ahedo Santisteban, 2006; Castro Spila et al., 2010). Training, education, R\&D, industrial clusters and networks of SMEs have been proactively promoted by the regional government. In the new regional model, foreign subsidiaries seem to be playing a less important role than other sources of extra-regional know-how (e.g. native MNEs, exporters, European R\&D projects), as suggested by an analysis of the Basque Information and Communication Technology (ICT) cluster (Valdaliso et al., 2011). In 2013, firms performing internal R\&D accounted for $55.3 \%$ of Basque firms but for only $35.3 \%$ of the foreign subsidiaries located in the region (ORKESTRA, 2015). Analysing an Italian technological district, Biggiero (2002) noted that the strongly socially embedded nature of districts made penetration of FDI quite slow; the process often started with joint-ventures with local firms. "Other local or regional systems, not as socially and culturally integrated and dense as industrial districts, would more easily allow for other types of entry", he added (p.120). It may well be that in the context of such 'dense' regional systems, MNEs are also gradually involved in regional corporate $R \& D$ activities. The discussion suggests that regional models of development may also affect the sub-national distribution of FDI in R\&D, but the studies summarised in Appendix 1 do not provide any theoretical guidance in this respect. These 
various reasons might contribute to explaining why the Basque Country turned out to be different from Madrid or Catalonia. However, these are only speculative interpretations and further research is clearly needed to assess their accuracy.

As stated, in our sample, the R\&D activities of domestic firms are more territorially dispersed. In line with previous analyses (Autant-Bernard, 2006; Kearns and Görg, 2002; Mariotti et al., 2010), we conclude that foreign subsidiaries and domestic firms differ concerning the location of their respective R\&D activities.

\subsection{Technologically advanced foreign subsidiaries}

The issue left unanswered is whether highly innovative foreign subsidiaries also tend to concentrate in the main FDI agglomerations. We therefore test whether, within the host country, technology leading foreign subsidiaries are attracted to or deterred from clustering in the most important regions. Given the state of the current debate on this topic, to build a model of deterrence is beyond the scope of this study. Available theoretical guidance and even empirical evidence are still lacking. Instead, this study has mainly an exploratory character. Therefore, we estimate a multinomial logit model, where the dependent variable takes on the value of 1 if the company is located in Madrid, value 2 if the company is located in Catalonia and 3 if the company is located elsewhere in Spain (loc1). The multinomial logit model was selected because descriptive statistics clearly indicated that foreign subsidiaries tended to group in Madrid and Catalonia. The sample here refers to foreign subsidiaries with $R \& D$ employees only, since we investigate the types of investors attracted. Our independent variable of interest concerns the foreign subsidiaries' technology status at sector level. We operationalise this variable following Berry's (2006) methodology. Specifically we include a dummy for technologically advanced firms. This dummy takes the value 1 if the foreign subsidiary is in the top quartile in its technological sector in terms of the number of R\&D employees per total sales in their respective technology sector and year (see Table 1 for definitions), and 0 otherwise. The technology status of the company is calculated with regard to its own technological sector, including both domestic firms and other foreign subsidiaries operating in Spain in the same sector.

Technological sectors are defined here in accordance with the OECD classification of industries by percentage of R\&D expenditure in total turnover: low technology intensity ${ }^{5}$, medium low technology intensity ${ }^{6}$, and medium high ${ }^{7}$ and high technology intensity ${ }^{8}$. Services are classified according to the EUROSTAT classification as high-tech services, low tech services and other services.

In the estimations, we also control for certain key characteristics of the foreign subsidiary that could additionally influence its location in the two leading regions or elsewhere in the host country. We control for the size of the subsidiary (measured as the $\log$ of the total number of employees). We also include patenting activities (patents) as an additional control for quality of innovation; note that these are the total patents granted to the foreign subsidiary (not those generated in specific Spanish regions). Further, we include a dummy for exports (export). Exporters may need to locate in highly connected cities with good access to transportation, such as global cities. Finally, we also control for the age of the firm (year of creation). The estimations include controls for 43 different industries. Appendix 2 shows the corresponding correlation matrix and descriptive statistics of the dependent and independent variables used here. 
Table 4 Logistic regression: main office location of firms that perform R\&D. Foreign subsidiaries and domestic firms

\begin{tabular}{|c|c|c|c|c|c|c|}
\hline & \multicolumn{4}{|c|}{$\begin{array}{l}\text { Madrid and Catalonia } \\
\text { versus rest of country }\end{array}$} & \multicolumn{2}{|c|}{$\begin{array}{l}\text { Madrid versus } \\
\text { rest of country }\end{array}$} \\
\hline & \multicolumn{2}{|c|}{ F. subsidiaries } & \multicolumn{2}{|c|}{ Domestic firms } & \multirow{2}{*}{$\begin{array}{c}F \\
\text { subsidiaries }\end{array}$} & \multirow{2}{*}{$\begin{array}{l}\text { Domestic } \\
\text { firms }\end{array}$} \\
\hline & Madrid & Catalonia & Madrid & Catalonia & & \\
\hline $\begin{array}{l}\text { Technologically } \\
\text { advanced }\end{array}$ & $\begin{array}{l}-0.732 * * \\
(0.306)\end{array}$ & $\begin{array}{l}-0.051 \\
(0.217)\end{array}$ & $\begin{array}{c}-0.335^{* *} \\
(0.167)\end{array}$ & $\begin{array}{c}0.046 \\
(0.142)\end{array}$ & $\begin{array}{c}-0.699 * * * \\
(0.286)\end{array}$ & $\begin{array}{c}-0.355^{* *} \\
(0.163)\end{array}$ \\
\hline Size $(\log )$ & $\begin{array}{c}0.449 * * * \\
(0.104)\end{array}$ & $\begin{array}{c}0.082 \\
(0.094)\end{array}$ & $\begin{array}{l}0.240^{* *} \\
(0.054)\end{array}$ & $\begin{array}{l}-0.046 \\
(0.058)\end{array}$ & $\begin{array}{c}0.406 * * * \\
(0.091)\end{array}$ & $\begin{array}{c}0.255^{* * *} \\
(0.053)\end{array}$ \\
\hline Patents & $\begin{array}{l}-0.170 \\
(0.318)\end{array}$ & $\begin{array}{c}0.099 \\
(0.248)\end{array}$ & $\begin{array}{l}-0.199 \\
(0.164)\end{array}$ & $\begin{array}{c}0.287 * * \\
(0.141)\end{array}$ & $\begin{array}{l}-0.221 \\
(0.292)\end{array}$ & $\begin{array}{c}-0.302 * * \\
(0.157)\end{array}$ \\
\hline Export & $\begin{array}{c}0.041 \\
(0.381)\end{array}$ & $\begin{array}{c}0.093 \\
(0.365)\end{array}$ & $\begin{array}{l}0.402 * * \\
(0.173)\end{array}$ & $\begin{array}{c}0.560 * * * \\
(0.166)\end{array}$ & $\begin{array}{l}-0.016 \\
(0.338)\end{array}$ & $\begin{array}{c}0.263 \\
(0.168)\end{array}$ \\
\hline Year of creation & $\begin{array}{l}-0.007 \\
(0.006)\end{array}$ & $\begin{array}{l}-0.006 \\
(0.005)\end{array}$ & $\begin{array}{l}-0.006^{*} \\
(0.005)\end{array}$ & $\begin{array}{c}-0.015 * * * \\
(0.004)\end{array}$ & $\begin{array}{l}-0.004 \\
(0.006)\end{array}$ & $\begin{array}{l}-0.001 \\
(0.003)\end{array}$ \\
\hline Log likelihood & & $-1,382.7$ & & $-3,671.0$ & -645.7 & $-1,770.4$ \\
\hline Pseudo R2 & & 0.179 & & 0.150 & 0.239 & 0.180 \\
\hline $\begin{array}{l}\text { Number of } \\
\text { observations }\end{array}$ & & 1574 & & 4355 & 1574 & 4355 \\
\hline
\end{tabular}

Notes: Standard errors robust to clustering at the firm level are presented in parenthesis; $* * *, * *, *=$ statistically significant at the 99,95 and $90 \%$ levels. All estimations include 43 unreported sector dummies, year dummies and a constant.

Source: PITEC 2009-2011

Results are presented in Table 4, columns 1 and 2. Our most important result is that conditional on other controls - the foreign subsidiaries which are most technologically advanced in their sector appear to avoid location in Madrid. However, we also find that the largest subsidiaries have a higher probability of locating in Madrid. ${ }^{9}$

In columns 3 and 4 we carry out the same analysis for domestic firms. For Madrid, we observe a very similar picture, as the most technologically advanced domestic firms also show a lower probability of locating in Madrid. In contrast, larger domestic firms and exporting and younger domestic firms have a higher probability of locating in Madrid. Exporting and the age of the company are not significantly related to foreign subsidiary location. For Catalonia, the dummy for the most technologically advanced firms is again not significant as in the case of foreign subsidiary location. We observe however, that domestic firms that have been granted patents show a higher probability of location in Catalonia compared to the rest of the country. As in the case of Madrid, exporting domestic firms and younger domestic firms also have a higher probability of location in Catalonia compared to the rest of the country. None of these variables shows up as significant in the case of Catalonia in the foreign subsidiary sample in column 2.

Madrid is the only Spanish city which ranks as a global city (Iammarino and McCann, 2013). ${ }^{10}$ In column 5 we, therefore, focus specifically on Madrid. We estimate a binary logit model, where the dependent variable takes on the value of 1 if the company is located in Madrid and 0 otherwise (loc2). Again, our result that the largest though not most technology advanced foreign subsidiaries are attracted to Madrid is confirmed. In this context, our results provide support to the deterrence literature. Finally, as we are 
especially interested in the specificities of the R\&D location of foreign subsidiaries within the host country, we have again repeated our analysis with the sample of domestic R\&D firms (column 6). We observe a similar pattern of deterrence of the technologically most advanced domestic companies from Madrid; moreover, in this case patentors also tend to avoid location in Madrid. Thus, the deterrence of the most technologically advanced foreign companies cannot be viewed as a specificity of foreign subsidiary R\&D location. Moreover, we can conclude that the most technologically advanced FDI in R\&D was not deterred by the grouping of domestic technology leaders since these companies also tend to avoid location in Madrid.

The analysis in Table 4 is based on the main office location of foreign subsidiaries which have R\&D employees in Spain. Most foreign subsidiaries in our sample only have a presence in one region $(85 \%)$, thus the main office location coincides with the location of their R\&D laboratories in most cases. However, as a robustness check we have re-run our analysis where we base the subsidiary location in the region where the foreign subsidiary has most of its R\&D employees, i.e. its main laboratory. Results are qualitatively the same and are available upon request.

\section{Conclusions}

We provided an exploratory study of the sub-national location of FDI in R\&D in Spain. In doing so, we contributed as follows to the literature. The sub-national distribution of FDI in R\&D has rarely been studied in the extant literature. Moreover, of the few available studies, most do not employ a control group of domestic firms to observe specificities of foreign subsidiaries. In contrast, we analyse a large national database for a catching-up country, which allows us to compare the R\&D sub-national locations of domestic firms and foreign subsidiaries. In addition, most of the extant literature on FDI in R\&D at sub-national level focuses on regional attractors. Considering, therefore, that the research field of the relationship between the characteristics of foreign-owned R\&D and the location of these activities is still relatively unexplored, we focused on certain characteristics of these companies, namely the organisation of their R\&D activities (open innovation) and their technological leadership in host industries. A reason for selecting these characteristics is that their presence may be desirable from the point of view of host regions and, in general, of host countries engaged in technological upgrading. We also controlled for other firm specific characteristics, such as size. We found that foreign laboratories tend to locate in the leading regions, Madrid and Catalonia, while domestic laboratories are more spatially dispersed. However, our results for location in the Basque Country provide an interesting counterpoint to the widely held notion that prosperous and technology rich regions tend to attract FDI in R\&D.

Concerning location of their innovative activities, foreign subsidiaries are not a homogeneous group. When we specifically analysed networked foreign firms involved in external technology sourcing (as opposed to those which exclusively source technology within their own group), we noted that their R\&D activities are still more concentrated in Madrid and Catalonia. Though this finding seems to support the idea that foreign subsidiaries engaged in open innovation significantly contribute to cluster formation, an important limitation of our study in this respect is that the available data do not provide information about eventual regional partners or R\&D suppliers of the sample firms. Such data would be important to shed light on localised R\&D outsourcing and cooperation 
patterns occurring between co-located firms. Finally, the most technologically advanced foreign subsidiaries are not attracted to Madrid, in spite of the alleged advantages of global cities in terms of openness and connectivity. However, technologically advanced domestic firms follow a similar location strategy. This finding is in accordance with the deterrence literature.

Our results clearly point to the interest of including MNEs' technological strategies in analyses of the sub-national distribution of foreign-owned R\&D. A policy implication of the analysis is that, in countries that are not at the forefront in science and technology, many regions need to be chiefly reliant on local and national capabilities. In many of these regions the contribution of domestically-owned R\&D is outstanding and needs to be supported. On the other hand, foreign subsidiaries and domestic firms do not perform R\&D exactly in the same Spanish regions. This circumstance may limit transfers of technology from FDI in R\&D, as suggested by studies on Ireland and certain emerging economies (Beausang, 2003; Görg and Ruane, 2001). Further research is needed to overcome the limitations of our study. Are the open innovation strategies of foreign subsidiaries likely to promote cluster formation in host countries? What concrete microdecisions lead to deterrence in leading foreign subsidiaries? Can the model of development prevalent in regions (e.g. densely socially embedded networks) affect the sub-national distribution of FDI in R\&D? Responses to these questions would certainly increase our understanding of the sub-national location of FDI in R\&D.

\section{Acknowledgements}

We gratefully acknowledge the financial support of the Spanish Ministry of Economy and Competitiveness (ECO2010-17485 and ECO2013-41317-R). We are also grateful to two anonymous referees for their helpful comments and suggestions.

\section{References}

Abadie, A. and Gardeazabal, J. (2003) 'The economic costs of conflict: a case study of the Basque Country', The American Economic Review, Vol. 93, No. 1, pp.113-132.

Ahedo Santisteban, M. (2006) 'Business systems and cluster policies in the Basque Country and Catalonia (1990-2004)', European Urban and Regional Studies, Vol. 13, No. 1, pp.25-39.

Alcácer, J. and Chung, W. (2013) 'Location strategies for agglomeration economies', Strategic Management Journal, Vol. 35, No. 12, pp.1749-1761, DOI: 10.1002/smj.2186.

Almeida, P. (2004) 'Subsidiaries and knowledge creation: the influence of the MNC and host country on innovation', Strategic Management Journal, Vol. 25, Nos. 8-9, pp.847-864.

Almeida, P. and Kogut, B. (1997) 'The exploration of technological diversity and geographic localization in innovation: start-up firms in the semiconductor industry', Small Business Economics, Vol. 9, No. 1, pp.21-31.

Andersson, U., Björkman, I. and Forsgren, M. (2005) 'Managing subsidiary knowledge creation: the effect of control mechanisms on subsidiary local embeddedness', International Business Review, Vol. 14, No. 5, pp.521-538.

Asheim, B.T., Coenen, L., Moodysson, J. and Vang, J. (2007) 'Constructing knowledge-based regional advantage: implications for regional innovation policy', Int. J. of Entrepreneurship and Innovation Management, Vol. 7, Nos. 2/3/4/5, pp.140-155.

Autant-Bernard, C. (2006) 'Where do firms choose to locate their R\&D? A spatial conditional logit analysis on French data', European Planning Studies, Vol. 14, No. 9, pp.1187-1208. 
Beausang, F. (2003) 'Multinational enterprise (MNE) supplier networks: organizational innovation of innovation policy?', Journal of Comparative International Management, Vol. 6, No. 2, pp. $20-41$.

Bel, G. and Fageda, X. (2008) 'Getting there fast: globalization, intercontinental flights and location of headquarters', Journal of Economic Geography, Vol. 8, No. 4, pp.471-495.

Belderbos, R., Van Roy, V., Leten, B. and Thijs, B. (2014) 'Academic research strengths and multinational firms' foreign R\&D location decisions: evidence from foreign R\&D projects in European regions', Environment and Planning A, Vol. 46, No. 4, pp.920-942.

Berry, H. (2006) 'Leaders, laggards, and the pursuit of foreign knowledge', Strategic Management Journal, Vol. 27, No. 2, pp.151-168.

Biggiero, L. (2002) 'The location of multinationals in industrial districts: knowledge transfer in biomedicals', The Journal of Technology Transfer, Vol. 27, No. 1, pp.111-122.

Blanc, H. and Sierra, C. (1999) 'The internationalisation of R\&D by multinationals: a trade-off between external and internal proximity', Cambridge Journal of Economics, Vol. 23, No. 2, pp.187-206.

Cantwell, J. and Iammarino, S. (2000) 'Multinational corporations and the location of technological innovation in the UK regions', Regional Studies, Vol. 34, No. 4, pp.317-332.

Cantwell, J. and Mudambi, R. (2011) 'Physical attraction and the geography of knowledge sourcing in multinational enterprises', Global Strategy Journal, Vol. 1, Nos. 3-4, pp.206-232.

Cantwell, J. and Piscitello, L. (1999) 'The emergence of corporate international networks for the accumulation of dispersed technological competences', MIR, Special Issue, No. 1, pp.123-147.

Cantwell, J. and Piscitello, L. (2002) 'The location of technological activities of MNCs in European regions: the role of spillovers and local competencies', Journal of International Management, Vol. 8, No. 1, pp.69-96.

Cantwell, J. and Piscitello, L. (2005) 'Recent location of foreign-owned research and development activities by large multinational corporations in the European regions: the role of spillovers and externalities', Regional Studies, Vol. 39, No. 1, pp.1-16.

Cantwell, J. and Santangelo, G.D. (2002) 'The significance of European small country regions in the geographical division of Labour of European Information and Communication Technology (ICT) Corporations', IJTM, Vol. 24, Nos. 7/8, pp.663-679.

Castro Spila, J., Rocca, L., Ibarra, A., Pradales, I., Vega, N. and Castro, C. (2010) 'Absorptive capacity, innovation networks and products: SME in the Basque Country', International Journal of Innovation and Regional Development, Vol. 2, No. 3, pp.182-197.

Crescenzi, R., Pietrobelli, C. and Rabellotti, R. (2014) 'Innovation drivers, value chains and the geography of multinational corporations in Europe', Journal of Economic Geography, Vol. 14, No. 6, pp.1053-1086.

Crozet, M., Mayer, T. and Mucchielli, J.L. (2004) 'How do firms agglomerate? A study of FDI in France', Regional Science and Urban Economics, Vol. 34, No. 1, pp.27-54.

Defever, F. (2006) 'Functional fragmentation and the location of multinational firms in the enlarged Europe', Regional Science and Urban Economics, Vol. 36, No. 5, pp.658-677.

Dunning, J. (1998) 'Location and the multinational enterprise: a neglected factor?', Journal of International Business Studies, Vol. 29, No. 1, pp.45-66.

Dunning, J.H. and Lundan, S.M. (2009) 'The internationalization of corporate R\&D: a review of the evidence and some policy implications for home countries', Review of Policy Research, Vol. 26, Nos. 1-2, pp.13-34.

European Commission (2009) Regional Innovation Scoreboard 2009, Belgium.

Fernández-Otheo, C.M. (2014) 'La Inversión Exterior Directa Recibida: Estructura Sectorial y por Países. Rentabilidad', in Myro, R. (Ed.): España en la Inversión Directa Internacional, pp.125-158, Instituto de Estudios Económicos, Madrid. 
Ferreiro, J., Rodriguez, C. and Serrano, F. (1997) 'The role of foreign direct investment in an old industrial region: the case of the Basque country and Japanese FDI', European Planning Studies, Vol. 5, No. 5, pp.637-657.

Frost, T.S. (2001) 'The geographic sources of foreign subsidiaries' innovation', Strategic Management Journal, Vol. 22, No. 2, pp.101-123.

Frost, T.S. and Zhou, C. (2000) 'The geography of foreign R\&D within a host-country. An evolutionary perspective on location-technology selection by multinationals', Int. Studies of Mgt. \& Org., Vol. 30, No. 2, pp.10-43.

Goerzen, A., Asmussen, C.G. and Nielsen, B.B. (2013) 'Global cities and multinational enterprise location strategy', J. Int. Bus. Stud, Vol. 44, No. 5, pp.427-450.

Görg, H. and Ruane, F. (2001) 'Multinational companies and linkages: panel-data evidence for the Irish electronics sector', Int. J. of the Economics of Business, Vol. 8, No. 1, pp.1-18.

Guimarães, P., Figueiredo, O. and Woodward, D. (2000) 'Agglomeration and the location of foreign direct investment in Portugal', Journal of Urban Economics, Vol. 47, No. 1, pp.115-135.

Head, K. and Mayer, T. (2004) 'Market potential and the location of Japanese investment in the European Union', The Review of Economics and Statistics, Vol. 86, No. 4, pp.959-972.

Hilber, C.A.L. and Voicu, I. (2010) 'Agglomeration economies and the location of foreign direct investment: empirical evidence from Romania', Regional Studies, Vol. 44, No. 3, pp.355-371.

Ho, H-C. (2006) On Explaining Locational Patterns of R\&D Activities by Multinational Enterprises, Eindhoven University Press, Eindhoven, The Netherlands.

Iammarino, S. and McCann, P. (2013) Multinationals and Economic Geography. Location, Technology and Innovation, Edward Elgar, Cheltenham, UK.

Kearns, A. and Görg, H. (2002) 'Linkages, agglomerations and knowledge spillovers in the Irish electronics industry: the regional dimension', Int. J. of Technology Management, Vol. 24, Nos. 7/8, pp.743-763.

Mariani, M. (2002) 'Next to production or to technological clusters? The economics and management of R\&D location', Journal of Management and Governance, Vol. 6, No. 2, pp.131-152.

Mariotti, S. and Piscitello, L. (1995) 'Information costs and location of FDI within the host-country: empirical evidence from Italy', Journal of International Business Studies, Vol. 26, No. 4, pp.815-841.

Mariotti, S., Piscitello, L. and Elia, S. (2010) 'Spatial agglomeration of multinational enterprises: the role of information externalities and knowledge spillovers', Journal of Economic Geography, Vol. 10, No. 4, pp.519-538.

McCann, P. and Mudambi, R. (2004) 'The location behaviour of the multinational enterprise: some analytical issues', Growth and Change, Fall, Vol. 35, No. 4, pp.491-524.

McCann, P. and Mudambi, R. (2005) 'Analytical differences in the economics of geography: the case of the multinational firm', Environment and Planning A, Vol. 37, No. 10, pp.1857-1876.

Miravitlles, P., Guitart-Tarrés, L., Achcaoucaou, F. and Núñez-Carballosa, A. (2013) 'The role of the environment in the location of R\&D and innovation activities in subsidiaries of foreign multinationals', Innovation: Management, Policy \& Practice, Vol. 15, No. 2, pp.170-83.

Narula, R. and Santangelo, G.D. (2012) 'Location and collocation advantages in international innovation', Multinational Business Review, Vol. 20, No. 1, pp.6-25.

OECD (2005) 'Internationalisation of R\&D: trends, issues and implications for S\&T policies. A review of the literature', Paper presented at Forum on the Internalisation of R\&D, Brussels.

ORKESTRA (2015) Cuadernos del Informe de Competitividad del País Vasco 2015. Factores empresariales, Bilbao.

Pelegrín, A. and Bolancé, C. (2008) 'Regional foreign direct investment in manufacturing. Do agglomeration economies matter?', Regional Studies, Vol. 42, No. 4, pp.505-522. 
Phelps, N.A. (1993) 'Branch plant and the evolving spatial division of labour: a study of material linkage change in the Northern Region of England', Regional Studies, Vol. 27, No. 2, pp.87-101.

Royo, S. (2008) Varieties of Capitalism in Spain: Remaking the Spanish Economy for the New Century, Palgrave MacMillan, London-New York.

Sanz Menéndez, L. and Arias, E. (1998) 'Un análisis a través de las patentes europeas. Concentración y especialización regional de las capacidades tecnológicas', Economía Industrial, Vol. 324, pp.105-122.

Shaver, J.M. and Flyer, F. (2000) 'Agglomeration economies, firm heterogeneity, and foreign direct investment in the United States', Strategic Management Journal, Vol. 21, No. 12, pp.1175-1193.

Shaver, M.J. (1998) 'Do foreign-owned and U.S.-owned establishments exhibit the same location patterns in U.S. manufacturing industries?', Journal of International Business Studies, Vol. 29, No. 3, pp.469-492.

Siedschlag, I., Smith, D., Turcu, C. and Zhang, X. (2013) 'What determines the location choice of R\&D activities by multinational firms?', Research Policy, Vol. 42, No. 8, pp.1420-1430.

Suárez-Villa, L. (2002) 'High technology clustering in the polycentric metropolis: a view from the Los Angeles metropolitan region', Int. J. Technology Management, Vol. 24, Nos. 7/8, pp.818-842.

Suárez-Villa, L. and Walrod, W. (1997) 'Operational strategy, R\&D and intra-metropolitan clustering in a polycentric structure: the advanced electronics industries of the Los Angeles Basin', Urban Studies, Vol. 34, No. 9, pp.1343-1380.

UNCTAD (2012) World Investment Report 2012, UNCTAD, Geneva.

Valdaliso, J., Elola, A., Aranguren, M.J. and Lopez, S. (2011) 'Social capital, internationalization and absorptive capacity: the electronics and ICT cluster of the Basque Country', Entrepreneurship \& Regional Development, Vol. 23, Nos. 9-10, pp.707-733.

Veugelers, R. and Cassiman, B. (2004) 'Foreign subsidiaries as a channel of international technology diffusion: some direct firm level evidence from Belgium', European Economic Review, Vol. 48, No. 2, pp.455-476.

Villaverde, J. and Maza, A. (2012) 'Foreign direct investment in Spain: regional distribution and determinants', International Business Review, Vol. 21, No. 4, pp.722-733.

Villaverde, J. and Maza, A. (2015) 'The determinants of inward foreign direct investment: evidence from the European regions', International Business Review, Vol. 24, No. 2, pp.209-223.

Voinea, C.L. and Van Kranenburg, H. (2011) 'Colocation patterns of foreign-owned firms in a small open economy: evidence from the Netherlands', European Planning Studies, Vol. 19, No. 12, pp.2047-2072.

\section{Notes}

1 For an analysis of the regional distribution of FDI in Spain, see for example, Pelegrín and Bolancé (2008) or Villaverde and Maza (2012).

2 http://ec.europa.eu/eurostat/web/nuts/overview (accessed August 2015).

3 Note, we exclude public sector companies and research organisations from our analysis.

$4 \mathrm{http} / /$ www.ine.es/jaxi/menu.do?type=pcaxis\&path=/t37/p227/p01\&file=inebase $($ accessed July 2015).

5 Includes wood, pulp, paper and printing; food, beverages and tobacco; and textiles, leather and footwear.

6 Includes building and repairing of ships; rubber and plastics; coke and refined petroleum; other non-metallic mineral products; basic metals and manufactured metal products. 
7 Includes electrical machinery; motor vehicles; chemicals (excluding pharmaceuticals); railroad equipment; and machinery and equipment.

8 Includes aircraft and spacecraft; pharmaceuticals; office and computing machines; radio, TV and communications equipment; medical, precision and optical instruments. While the OECD classification has four categories, here the medium-high and high R\&D intensity classes were collapsed to avoid thin cells in cross-tabulations.

9 As a robustness check we have restricted our sample to younger firms, using only those created after 1995. Younger firms may have followed a different pattern. In these estimations, our main result is confirmed (available upon request).

10 The global city index (GCI) is built with data taken from the OECD, the World Bank and other sources. In 2008, Madrid's GCI was 58.34. Note that Amsterdam's GCI was 60.06 the same year. 


\section{Appendix 1}

Location of FDI in R\&D within host-countries: a selection of empirical studies

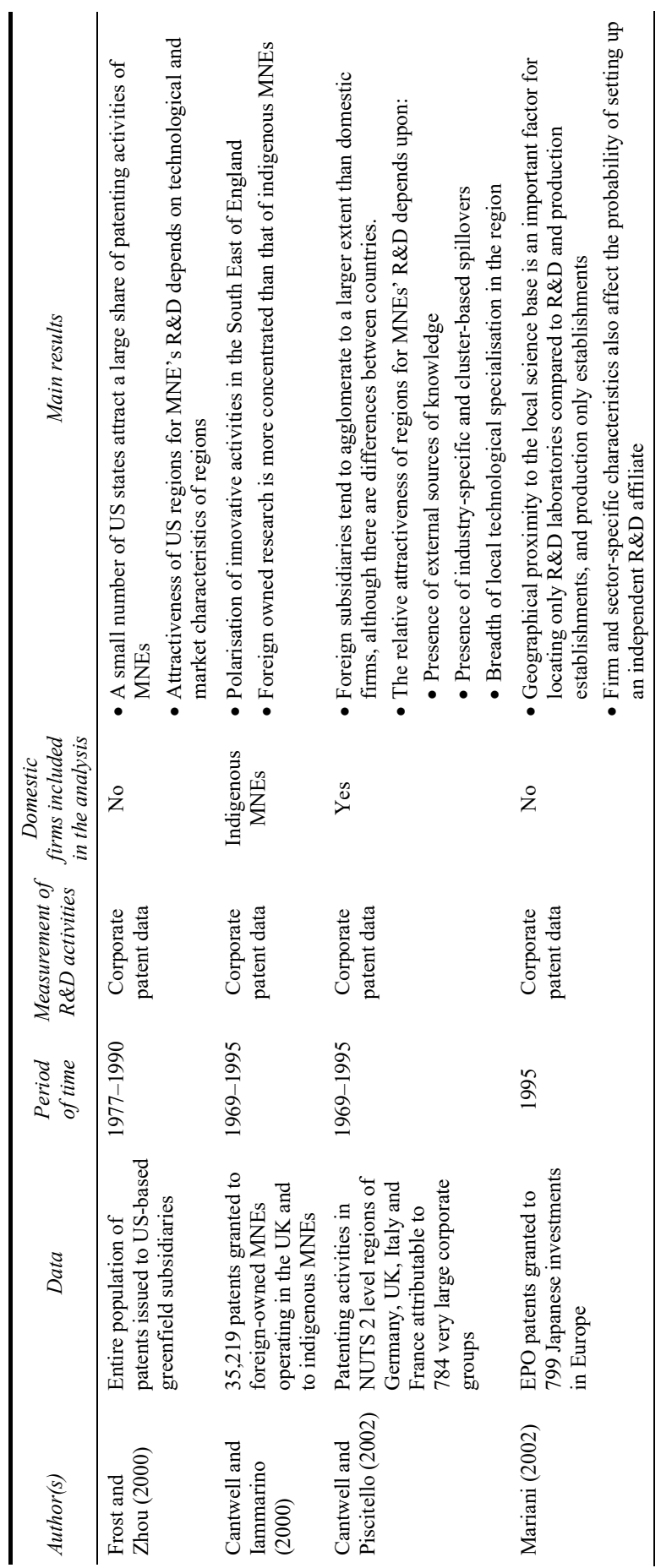


Location of FDI in R\&D within host-countries: a selection of empirical studies (continued)

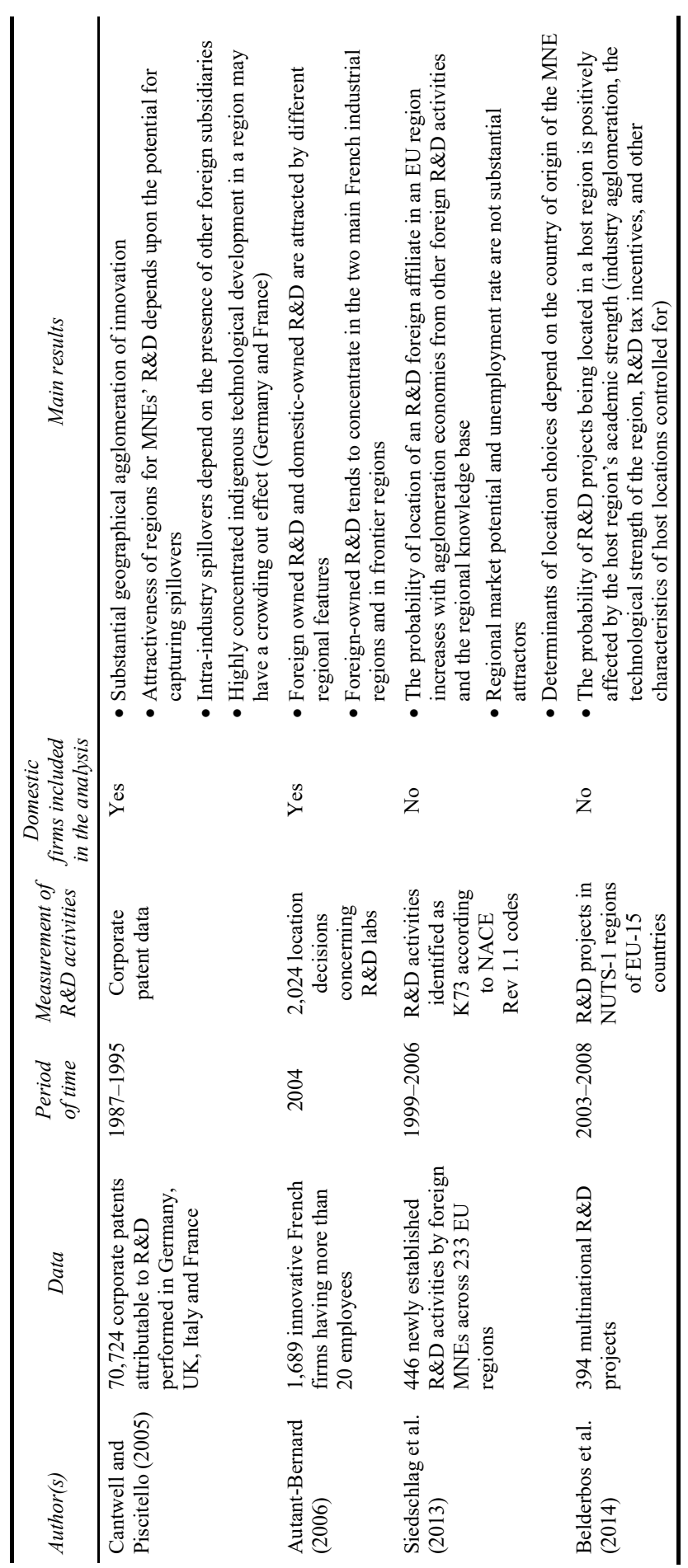




\section{Appendix 2}

Correlation matrix and descriptive statistics of dependent and independent variables used in Table 4

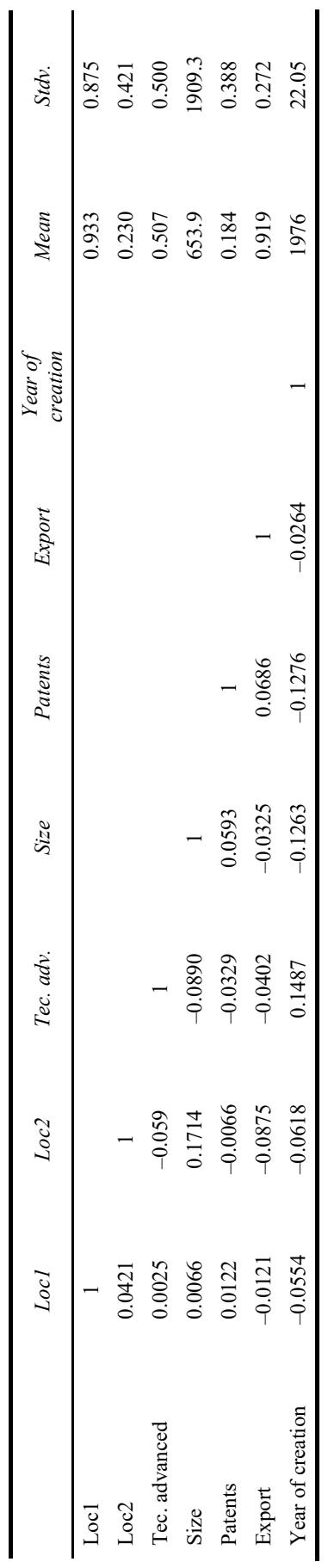

